\title{
Building a national public health system
}

\section{Carolyn Bennett}

ß See related article page 1378

$\mathrm{T}$ hirty years ago, with the publication of New Perspectives on the Health of Canadians, ${ }^{1}$ then Health Minister Marc Lalonde led the world in the understanding that achieving good health for a population requires more than just a good health care system. An equally important but often overlooked aspect of his prescient report is that it demonstrated the benefits of an integrated and coherent federal government approach to public health.

Just as the concept of balance was central to Lalonde's vision - a balance between investing in the "upstream" of public health and illness prevention and as well as in the "downstream" of health care delivery - so too was the need to rebalance our system central to the decision by Prime Minister Paul Martin to appoint a Minister of State for Public Health. This decision affirms the government's commitment to dealing with emerging infectious diseases such as SARS, improving emergency preparedness and reversing epidemics of chronic diseases such as diabetes and obesity.

The establishment of the new Public Health Agency of Canada is only one component of the Canadian government's broader strategy to strengthen the national public health system. That strategy builds on the reports prepared in the aftermath of last year's SARS outbreak by David Naylor, chair of the National Advisory Committee on SARS and Public Health, ${ }^{2}$ and by the Senate Standing Committee on Social Affairs, Science and Technology. ${ }^{3}$ It also builds on my own cross-country consultations with expert stakeholders and ordinary Canadians on ways to improve public health in Canada.

The strategy has three parts. The first part is to strengthen intergovernmental cooperation on public health. Simply creating a new agency will do little to address weaknesses in Canada's ability to anticipate and respond to outbreaks of infectious diseases and other threats to public health. Nor will it resolve structural inadequacies within Canada's broader system of public health response. That is why Canada's Health Ministers have agreed to move forward together to improve public health infrastructure and to develop an integrated national public health strategy.

The $\$ 665$ million announced in the federal budget will increase emergency response capacity, build a national high-quality real-time public health surveillance system and address priority gaps in provincial and territorial public health systems. The new Public Health Agency of Canada will be specifically mandated to build on strengths and capacities that exist across the country and foster collaboration with all levels of government on issues of Public Health. This new funding will support the establishment of regional centres of applied research, a national immunization strategy and will also be used to strengthen international coordination. In future budgets, the Government will build on this significant initial investment. In parallel with developing the Public Health Agency of Canada, I, along with the Minister of Health, will be working with our provincial and territorial counterparts to formalize our shared commitments and understandings.

Second, the Public Health Agency of Canada will operate at arm's length from government and will be accountable to Canadians through the Minister of Health. The new agency will serve as a focal point in the federal system for leadership and accountability on public health matters, including public health emergency response. The initial foundation of the Public Health Agency will be Health Canada's existing Population and Public Health Branch, which comprises some 1100 employees and has an annual budget in excess of $\$ 400$ million. Over time, the Public Health Agency will be broadened to encompass other relevant public health responsibilities and resources from Health Canada or from other federal departments and agencies. We will make further investments in the Public Health Agency and in a coordinated public health network for Canada, beyond the $\$ 665$ million in new funding announced in the 2004 Budget, once current Health Canada programs that are subsumed by the Agency have been evaluated and strategic plans and budgets have been developed.

Guided by the best available science and evidence to ensure it contributes to the sustainability of Canada's health care system, the Public Health Agency will be performance driven, deliver meaningful results and be accountable to Canadians. My intention is to make the agency a model for transparency in the federal system. As such, it will incorporate both formal and informal advisory structures that will enable it to benefit from the knowledge and expertise that exists in Canada's public health community. The agency will also maintain effective mechanisms for direct citizen engagement to ensure that its policies and programs are relevant and responsive to the priorities identified by Canadians.

The third component of the strategy is to appoint a Chief Public Health Officer for Canada. He or she will 
serve as chief executive officer of the new Agency and will have a leading role in developing, implementing and promoting federal priorities, programs and services in the area of public health. The Chief Public Health Officer must become a widely recognized symbol of national commitment to the protection and improvement of the health of Canadians. Accordingly, he or she will be expected to play a leadership and advocacy role in national public health matters, civic and health literacy as well as in advancing Canada's international public health interests.

We will shortly be announcing the recruitment process for the Chief Public Health Officer. The process will be an open and transparent one, designed to identity the best qualified candidate for the position.

Well over a century ago, Dr. Elizabeth Blackwell, North America's first woman physician and a crusader for public health and disease prevention, described her vocation as follows:

We are not tinkers who merely patch and mend what is broken ...We must be watchmen, guardians of the life and the health of our generation, so that stronger and more able generations may come after. ${ }^{4}$

I cannot agree more. Too much of our focus in recent years has been on the health care delivery end of the continuum - "the tyranny of the acute" - at the expense of public health and illness prevention. Creating the Public Health Agency for Canada is an important step in connect- ing the dots between investments in public health and the sustainability of our health care system. The goal of keeping as many Canadians healthy for as long as possible is a shared responsibility of governments, providers and citizens themselves. Together, we can lead the world again by setting ambitious goals and being accountable for our results. Canadians deserve no less.

The Hon. Carolyn Bennett, MD, is the Minister of State for Public Health.

Competing interests: None declared.

\section{References}

1. Lalonde M. A new perspective on the health of Canadians: a working document (1974). Ottawa: Ministry of Supply and Services Canada; 1981. Cat. no. H31-1374. Available: www.hc-sc.gc.ca/hppb/phdd/pube/perintrod.htm (accessed 2004 Apr 5).

2. The National Advisory Committee on SARS and Public Health. Learning from SARS: renewal of Public Health in Canada. Ottawa: Health Canada; 2003. Available: www.hc-sc.gc.ca/english/protection/warnings/sars/learning .html (accessed 2004 Apr 5).

3. Standing Senate Committee on Social Affairs, Science and Technology. The health of Canadians: the federal role. Final report on the state of the health care system in Canada. Ottawa: 2002. Available: www.parl.gc.ca/37/2/parlbus /commbus/senate/com-e/soci-e/rep-e/repoct02vol6-e.htm (accessed 2004 Apr 5).

4. Cited in Wanless D. Securing good health for the whole population: final report. London (UK): Department of Health; 2004. p. 6.

Correspondence to: The Hon. Carolyn Bennett, Brooke Claxton Building, Tunney's Pasture, Postal Locator 0914C, Ottawa ON K1A OK9; fax: 613-948-8445 